\title{
The Alun-Alun Karimunjawa as Economic Space in the Coastal City as Alun-Alun in the City Center in Java
}

\author{
R Siti Rukayah \\ Architecture Department, Faculty of \\ Engineering \\ Diponegoro University \\ Semarang, Indonesia \\ tututrsiti@yahoo.com
}

\author{
Endang Sri Susilo \\ Marine Science Department, Faculty of \\ Fisheries and Marine Science \\ Diponegoro University \\ Semarang, Indonesia \\ Dileanis Pringgenies \\ Marine Science Department, Faculty of \\ Fisheries and Marine Science \\ Diponegoro University \\ Semarang, Indonesia
}

\author{
Agus Tri Setyo W \\ Marine Science Department, Faculty of \\ Fisheries and Marine Science \\ Diponegoro University \\ Semarang, Indonesia
}

\begin{abstract}
Karimunjawa Island has the main activities of the population on the utilization of coral reef ecosystems, fisheries, and marine tourism activities. $60 \%$ of Karimunjawa people work as fishermen. The great support from the government makes Karimunjawa as one of the tourist destinations of the four-priority tourist area master plan, in addition to Borobudur, Sangiran, and Dieng and is projected to be able to attract foreign tourists. The main activity of local people as night culinary and souvenir area take place in the Alun-Alun / the traditional square. The potential of nature provides abundant seafood as raw materials, the potential workforce of the Karimunjawa community, especially the youth and women activity, as well as the potential market for tourists. The purpose of this study is to provide input to produce a better planning policy and urban design of the Alun-Alun. By using the grounded research method and public policy method found some potency of the Alun-Alun for local people economic activity of society. The square becomes the face of coastal tourism and display space of local products. Cooperation with related offices is an implementation of sustainability concept urban design of Alun-Alun as an economic space and display area.
\end{abstract}

Keywords- Alun-alun, Economic Space, Public Policy, Display Area

\section{INTRODUCTION}

Karimunjawa Islands administratively is the Karimunjawa District, Jepara Regency, Central Java Province with a land area of $\pm 1,500$ hectares and waters of \pm 110,000 hectares. The Karimunjawa islands are located in the Northwest of Jepara city with a distance of about 45 nautical miles or $83 \mathrm{~km}$. The main activity of the population of Karimunjawa Islands is generally the utilization around the coral reef ecosystem of TNKJ including fisheries and marine tourism activities. Most people depend on natural resources around them because economically reef fish are very important for fishermen. Yulianto et al., (2009) said that $70 \%$ of Karimunjawa's people work as fishers [1]. This indicates a high level of community dependence on fisheries resources.
Fine white sand spreads widely on many beaches that are still untouched, and the underwater beauty is the attraction of Karimunjawa. The total number of reef fish species in all Karimunjawa waters found during the survey up to 2006 are 353 species included in 117 genera and 43 families, and coral species are 64 genera of 14 scleractinian orders and 3 nonscleractinian orders [2]. Besides, the presence of some rare fauna that lives here is white chest albatrosses, hawksbill sea turtles, and green turtles which add to the attractiveness of Karimunjawa as a tourist destination for local and foreign tourists. This attraction is more complete with seafood which is served in the inn and sold in the square every night.

In recent years there has been a remarkable development in Karimunjawa. The square becomes a tourist center, especially nighttime culinary tourism. Determination of Karimunjawa as a tourist destination is also related to the great support from the government in encouraging tourism development in Karimunjawa. For Central Java, several cities have made the square as an economic space for local people such as Solo city and Pekalongan city [3-4]. Regarding this matter, the researchers want to examine how the Alun-Alun Karimunjawa has the potential as an economic space for local people.

\section{THEORETICAL FRAMEWORK}

\section{A. Squares on Java and History of Market Activities in Old Java Squares}

The square (Alun-Alun) has a function as a place for the state, custom and religious ceremonies. In the Majapahit era and ended in Mataram (13th-18th century), the square was even a meeting place for the king and the people [5\&3]. Rukayah (2010) finds that the activities of the state and religious ceremonies were in the square controlled by the mosque and palace [6].

In the colonial period, not far from the square and government buildings, there was a market as a commercial place [5\&3]. In the Javanese concept, a market is a gathering 
place for traders and buyers where there are two main activities, which are social interaction and transaction. This market activity is not related to the concept of power so its location must be outside the square. Rukayah (2012) states that the history of traditional market development initially occurred in an open space with a shade of trees without any permanent physical boundaries [7]. The need for a more representative shade gives birth to the physical building called the Los. However, the change into a modern building still rises the cycle of the return of traders as open space bazaars. Thus, this can be concluded that for the Javanese people, traditional markets are not just a place to buy and sell, but more than that, the market is related to the conception of life and socio-culture.

\section{B. Strategic Location in the City}

Rukayah (2018) says that the strategic location is a location that is often passed by many people. She also explains that there are certain areas in the city that are assumed strategic, namely the city square, and the main road corridor [3]. The city square becomes the strategic place since the city square is an open space, in the middle, and surrounded by buildings, such as government offices on the south side and mosques on the west side. So, the square is the appropriate place for economic activities, and others [3\&8]. According to Kostof (1992) in Memluk (2013), Alun-Alun (urban public square) has many economic benefits for the local community and can be a marketplace and commercial activity [8].

Urban road corridors are also a strategic area because of their function in linking economic activities [3]. The corridor like this is in Surakarta City called Mangkunegaran Corridor. The Mangkunegaran corridor covers the Pura Mangkunegaran area to the Singosaren Market (Matahari department store). This area is a strategic area because it is in the economic heart of Surakarta City. In the north, there is a night festival held every Saturday night. Street market activities in this region are different from the Galabo area (Snack Center in Solo city) which is held every night [9].

Pekalongan city also uses corridors/roads for economic activities. According to Rukayah et al (2014), the corridor now serves as a promotional medium for local people to display their industrial products. The corridor even develops into a shopping tourism area of Pekalongan, which is designed naturally from the participation of its people [4].

Both the square and the corridor/road are part of the city node. In his book entitled The Image of the City (1960), Lynch mentions that nodes in a city are strategic nodes or circles in which the direction or activity meets each other and can change in other directions or activities. The examples of the nodes are traffic intersections, stations, airports, bridges, cities as a whole on a large macro scale, markets, parks, squares, where a form of movement is circulated, and so on [10].

\section{Culinary Tourism}

According to online KBBI (2016), tourism is traveling together (to expand knowledge, have fun, etc.), sightseeing or picnic [11]. Meanwhile, culinary relates to cooking. It can be concluded that culinary tourism is a journey that utilizes cuisine and the atmosphere of the environment as a tourist attraction. Culinary tourism areas are usually located in strategic areas such as the main square and city corridors/roads.

For example, the city of Solo has heritage corridors. The Solo regional government utilizes the corridors for the commercial activities to improve the economy and tourist attractions. Solo City has an activity center in two places: Kasunanan Palace, and Mangkunegara Palace. The north side of the Kasunanan palace has been successfully designed as a street market and become a culinary tourism area. This area is known as Galabo or stands for Gladak Langen Bogan [3].

\section{Community Empowerment and Trade}

According to Widjaja (2003), community empowerment is an effort to improve the capabilities and potency of the community so that the community can realize their identity, and dignity to the maximum to survive independently in the economic, social, religious and cultural fields [12]. Community empowerment efforts are also contained in the provisions of Law 32 of 2004 (Undang-Undang 32 Tahun 2004) concerning Regional Government [13]. The efforts of community empowerment can be in various fields. This study refers to the economic field, especially in trade.

One of the efforts to empower the community in trade is to give the community a place to conduct economic activities, namely culinary tourism in strategic areas. By this, all people are directly involved and the main assets of tourism potential owned by SME (Small and Medium Enterprises) that are traditional drinks and food [3]. Community empowerment efforts in the economic field, especially trade, have been carried out by the local government of Solo city by opening Galabo as a culinary tourism destination and the traders are the local people.

\section{E. The Conclusion of Theoretical Framework}

The existence of a square in each city as the open space and often traversed by the community makes the square as a strategic place. Every strategic location will have a lot of potentials that can be utilized by the local government and the local community. One of them is by creating a culinary tourism area that serves a variety of foods, for example, typical regional food. Beside to increasing the local government revenue and making the location a distinctive feature of a city, the existence of culinary tourism in the square is also an effort to empower the local people because it involves the direct community by peddling their diverse SME products, such as traditional drinks and food. Solo, one of the cities in Central Java, has applied this.ocument. Please do not revise any of the current designations. 


\section{METHODOLOGY}

The method used in this study is the field survey by conducting the grounded research. The survey is conducted with a science and technology approach based on the local wisdom to be developed in groups of people who are directly in contact with the provision of Karimunjawa's local seafood products, namely the wives of fishermen, who at this time have not seen an active role in the development of culinary tourism in the Alun-Alun Karimunjawa. The data collection in the field includes the excavation of superior products that have high economic potential based on the local wisdom, and the application of innovation and institutional arrangements and mapping the location of the square as a strategic area for traders to conduct economic activities.

Various merchant data and mapping of merchant locations that utilize the square as a strategic selling place are analyzed by the research results in the field using urban design techniques [14]. The use of the square as an economic space is analyzed by using politics and economics in urban design [15].

\section{FIELD DATA}

\section{A. Alun-Alun Karimunjawa}

Alun-Alun Karimunjawa began to be crowded and became a culinary tourism area between 2010-2011. Alun-Alun Karimunjawa will appear quieter during the day, and there are only shopkeepers. However, when the evening comes, street vendors begin to crowded their merchandise both on weekdays and on holidays. In total there are forty-three traders who sell in this square, and it estimates that this number will continue to grow as the crowds of the Alun-Alun Karimunjawa increased by the tourists. Thirty-nine of them are street vendors while four other traders are traders who sell in shophouses around the square.

Products sold in Alun-Alun Karimunjawa are divided into two, namely souvenirs and clothing, and food and drinks. For street vendors, they sell a variety of products which are souvenirs and clothing, Karimunjawa wood crafts, typical food of Karimunjawa (crackers and salted fish), fried rice, chicken satay, wedang ronde, grilled seafood, mussels, and various juices and fried food. Meanwhile, the traders who sell at the shop, they provide food in the form of restaurants and typical souvenirs of Karimunjawa.

The layout of the traders which is quite a lot in the AlunAlun Karimunjawa has been arranged by the trade association of Alun-Alun Karimunjawa and supervised by Karimunjawa's villages and sub-districts. The following is the situation of Alun-Alun Karimunjawa (Figure 1), the layout of Alun-Alun Karimunjawa (Figure 2), and the surrounding area as well as the Google Maps of Alun-Alun Karimunjawa (Figure 3).

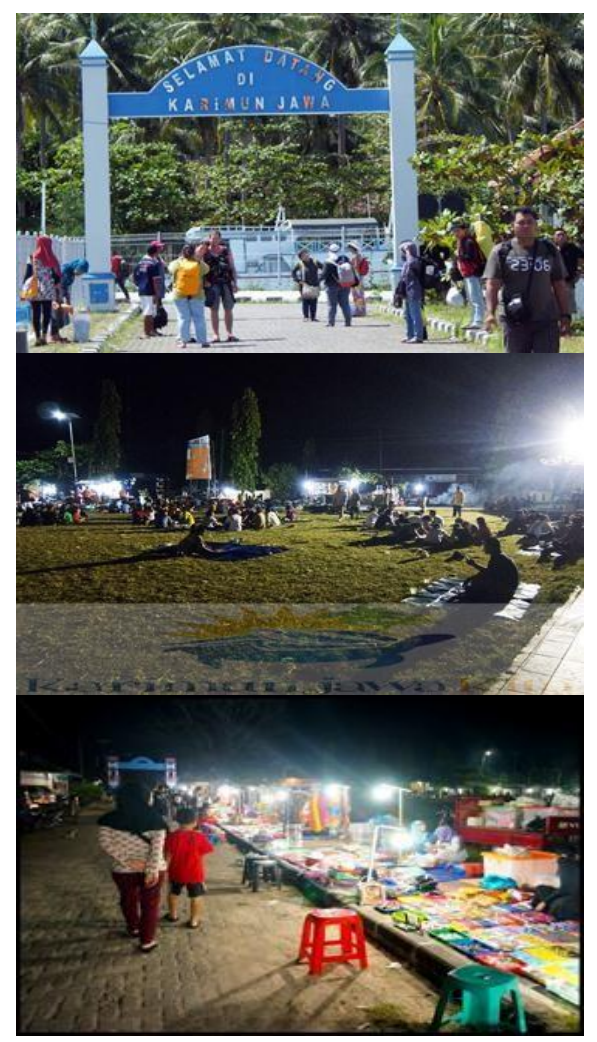

Figure 1. The Entrance Gate to Karimunjawa (Top), the Atmosphere of the Square at Night Shows Many Culinary Tours (Center), and Souvenir Shopping (Bottom).

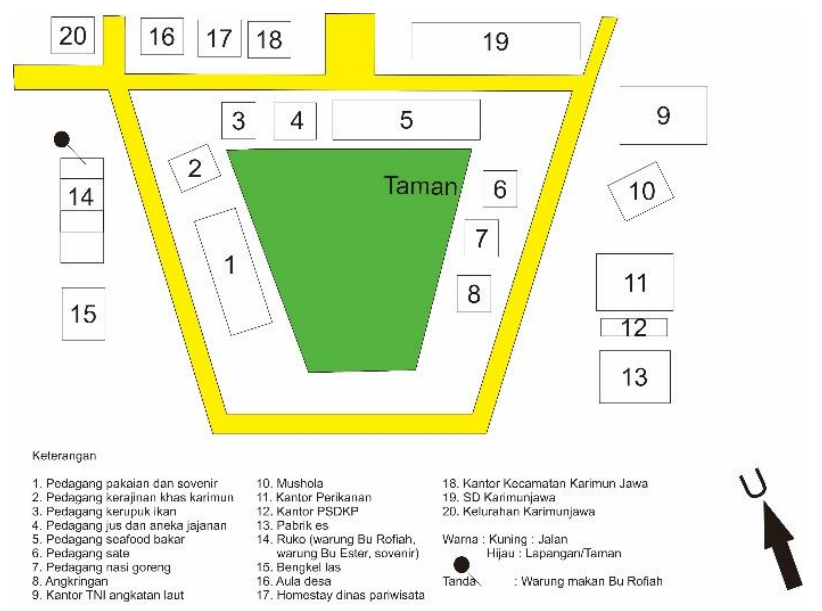

Figure 2. Trading Spatial of Alun-Alun Karimunjawa 


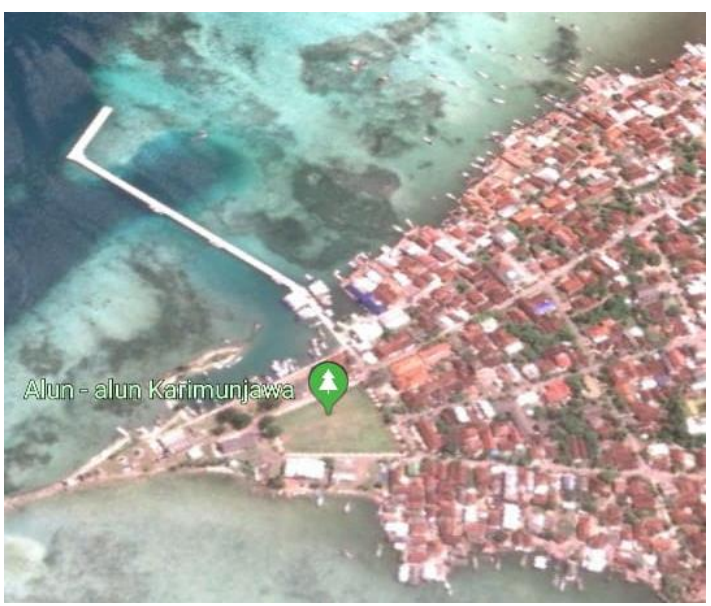

Figure 3. Google Maps of Alun-alun Karimunjawa

\section{B. Marine Products and Potential Workers from Local Communities}

Karimunjawa is one of the tourist destinations of four priority tourism master plan areas, in addition to Borobudur, Sangiran, and Dieng. Karimunjawa is also projected to be able to attract foreign tourists. The form of support for projecting Karimunjawa is by holding international activities, such as "Sail Krimunjawa" which is held every year.

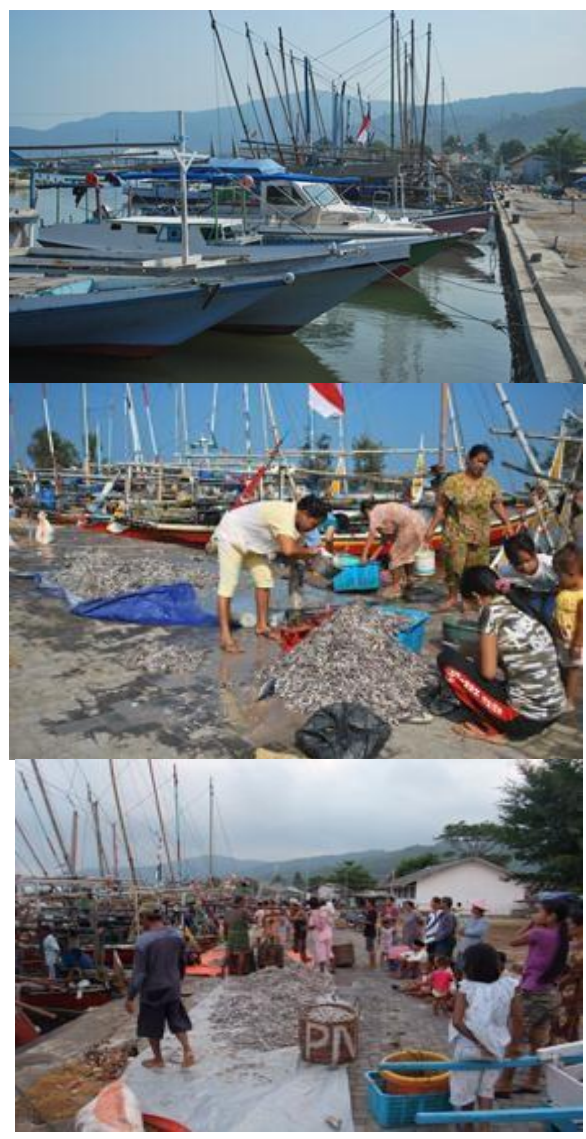

Figure 4. The Mooring of Tourist Boat Moorings alongside Fishing Boats at the Karimunjawa Beach Fishing Port

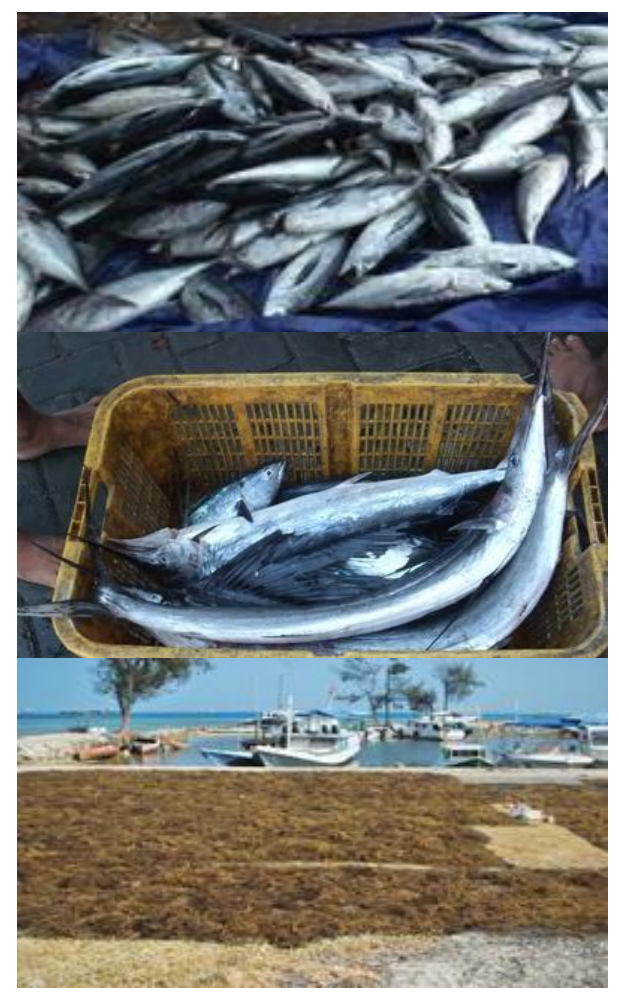

Figure 5. Various Fish Catches and Eucheuma Sp Seaweed Dried in the Fishing Ground

The potential of marine products from Karimunjawa waters is very abundant to support Karimunjawa's tourism development. The tourists can enjoy seafood on Alun-Alun every night with various dishes. In addition, dried anchovy is a typical seafood from Karimunjawa that can be brought home as a souvenir by the tourists. However, the presentation of all marine products is still very traditional and has not paid attention to the quality, and there is no technological touch for the added value of a product. The examples are during this time, the anchovy is only sold in dry form, processed fish is only limited to the traditional dishes and meatballs, and the crackers are made with the poor quality. It is ironic considering that seafood is very abundant and of the high quality because it is still fresh, there is a lot of potential labor from the Karimunjawa community, especially young people and mothers, and the potential large tourist markets and face to face with the people there. In addition to the results of food, the seafood from Karimunjawa is also very potential, such as gamat sea cucumbers which are in the great demand for medicine, and seaweed products for the industry. Thus, all of these marine products have the potential to be developed to increase their added value.

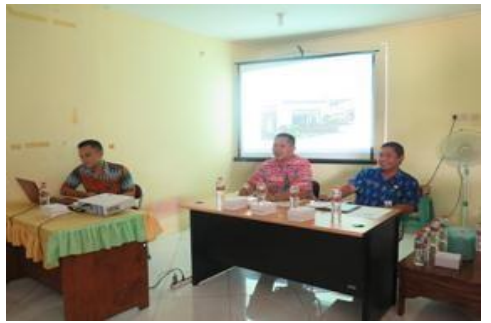




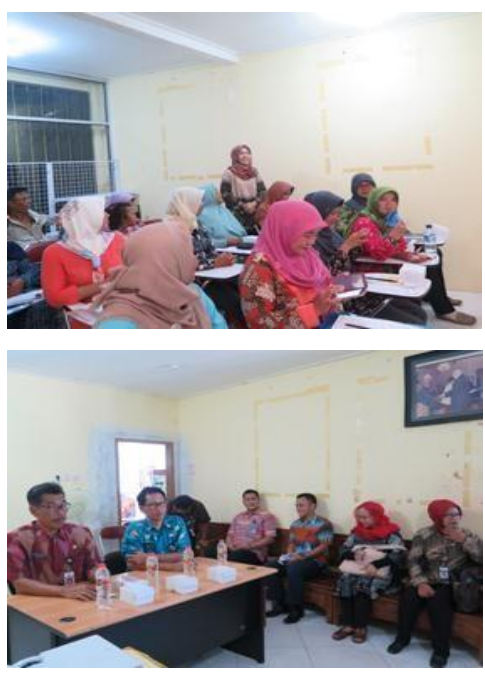

Figure 6. The Business Development Socialization, with Resource Persons from the Government, Business Actors and Central Java Banks

\section{ANALYSIS}

\section{A. Alun-Alun Karimunjawa, Potential of Alun-Alun and Market Activities in the Old Javanese Square}

Alun-Alun Karimunjawa looked from the shape, is different from the square in Java which is rectangular or square. The shape of Alun-Alun Karimunjawa is Trapezoid. Although the form of Alun-Alun Karimunjawa is different, the function of this square is the same as the square in general in Java, namely as an open space for various activities, including economic activities (market).

The economic activities in the form of trading around Alun-Alun Karimunjawa begin to be crowded in 2010-2011. At noon, this square will appear quiet by the traders. There are only a few traders who sell, and the place of sale is in the shop. However, when the evening comes, the street vendors begin to fill the square and sell various kinds of merchandise in the form of souvenirs and clothing, as well as drinks and food, including typical souvenirs of Karimunjawa (crackers and salted fish).

\section{B. Alun-Alun Karimunjawa and the Strategic Locations in the Cities}

In Java, the square is located in the city center with the government office on the south side and the mosque on the west side. The square is also located in a strategic location because it is often traversed by both local people and tourists. Alun-Alun Karimunjawa is also in the middle of Karimunjawa district. However, the Karimunjawa subdistrict office, which is the government office in Karimunjawa, is on the north side facing the south along with the Homestay of Tourism Office, Village Hall, Karimunjawa Village Office, and Karimunjawa Elementary School. The mosque, which is a religious activity site, is on the east side facing the west with several other buildings: the navy Army (TNI) office, Fisheries office, PSDK office, and Ice Factory. While on the west side, there are shop houses and welding workshops.
Although the position of buildings around Alun-Alun Karimunjawa is different from the square in Java, this still makes Karimunjawa square as the strategic location. This is since the location of Alun-Alun Karimunjawa is in the center of Karimunjawa district. Alun-Alun Karimunjawa is also surrounded by important buildings and is a city node that is often traversed by both local people and tourists. This also makes Alun-Alun Karimunjawa has the potential to be the open space for the economic activities for the local community.

\section{Culinary Tourism in Alun-Alun Karimunjawa}

The number of traders who sell their goods in Alun-Alun Karimunjawa in the evening, and the location of Alun-Alun Karimunjawa, which is strategic, this square have the potential to be used as a culinary tourism area. With the government support in spatial planning and developing this location, this will be one of the culinary tourism that will be a special attraction for tourists. Surely this culinary tourism will increase the local government income.

The culinary tourism in Alun-Alun Karimunjawa is also right because Karimunjawa itself is rich in kinds of seafood and can be processed as seafood in which many people like this. The culinary tourism in Alun-Alun Karimunjawa can also be used as a place to show the local products. However, what needs to consider is the processing of seafood which should be more creative and interesting, and packaging products that are more attractive and hygienic. So, tourists not only taste the seafood on the spot, but they can also bring the food to go home.

\section{Karimunjawa and Trade Community Empowerment}

The potential of Alun-Alun Karimunjawa as an economic space for the community and making it as a sea-themed culinary tourism area is able to become a place for local people to develop themselves through the world of trade, especially with culinary products. Karimunjawa's abundant sea potential will produce the marine products that can make Karimunjawa's marine processed food as a special food in Karimunjawa. There is also a lot of labor potential from the Karimunjawa community, especially the youth and mothers/wives of fishermen who play an active role in the supply of raw materials for seafood from Karimunjawa waters. All of this potential must utilize properly.

So far, the traders who sell in Alun-Alun Karimunjawa are only able to sell simple products. Most of the products sold are souvenirs and clothing, not Karimunjawa's seafood. There are even five shops that offer typical souvenirs of Karimunjawa in the square. Regarding the products sold by the traders in Alun-Alun Karimunjawa, there needs to be innovation from the products. Therefore, there needs to be motivation, as well as the transfer of knowledge and technology from the government and the university to the local community regarding the processing of Karimunjawa seafood to be more optimal. 


\section{CONCLUSION}

Tourism in Karimunjawa has experienced a very large development in recent years. The main attraction here is the beauty of the sea. However, the progress of tourism in Karimunjawa has not been offset by the support of the development of seafood innovations, both culinary and other as well as urban planning on the square as the face image of the city.

The potential of the square as the city center, natural potential, and human resources as well as the market in Karimunjawa are very large. All of them have not been optimally synergized. As a result, there is a disparity that can be seen between tourism actors directly, especially hotel and lodging entrepreneurs with fishermen.

The square becomes an economic space for people to sell there. A square is a culinary place with sea fish theme. The community/wives of fishermen are people who play an active role in the supply of raw materials for seafood from Karimunjawa waters. For this, there needs to be an active role from both universities and government to provide motivation, transfer of knowledge and technology, as well as mentoring until there is a layout design for the square.

The local knowledge built from the phenomenon in AlunAlun Karimunjawa complements the knowledge that the open space in the city center despite being surrounded by buildings like the square features traditional cities in Java, in which the open space still have functions that grow naturally or without being designed to become the economic space.

\section{ACKNOWLEDGMENT}

Thanks to Undip For Science Techno Tourism Development (UFST2D) 2018, Riset Publikasi Internasional 2018, and Riset Terapan Unggulan Perguruan Tinggi 2018. The gratitude also goes to the coastal women's organization Karimunjawa, the Marine and Fisheries Service of the Province of Central Java, Centre for the study of architecture and coastal cities that have been pleased to provide data in the field.

\section{REFERENCES}

[1] Yulianto I, Anggaraeni R, Listianingsih W, Prasetia R and Ripanto 2009 Laporan monitoring aspek sosial ekonomi dalam pengelolaan Taman Nasional Karimunjawa. Wildlife Conservation Indonesia Programme: Bogor, Indonesia

[2] Nababan, MG, Munasik, I Yulianto, T Kartawijaya, R Prasetia, R L Ardiwijaya, S T Pardede, R Sulisyati, Mulyadi and Y Syaifudin 2010 Status ekosistem di Taman Nasional Karimunjawa Wildlife Conservation Indonesia Programme, Bogor, pp. xi + 78

[3] Rukayah, Siti R 2018 Koridor Heritage dan Street Market di Kota Surakarta (Semarang: Biro Penerbit Planologi Undip)

[4] Rukayah, Ardiyan Adhi Wibowo, Sri Hartuti Wahyuningrum 2014 Batik shopping corridor as city branding of Pekalongan, Central Java, Procedia Social and Behavioral Sciences. www. Sciencedirect.com

[5] Handinoto 1992 Alun-alun sebagai identitas kota jawa, dulu dan sekarang Dimensi 18/ARS p 1-15

[6] Rukayah 2010 Simbiosis di Ruang Terbuka Kota Simpang Lima Semarang Unplublished Dissertation

[7] Rukayah, Bharoto 2012 Bazaar in urban open space as contain and container case study: alun-alun lama and simpang lima Semarang, Central Java, Indonesia Procedia Social and Behavioral Sciences www. Sciencedirect.com p 741-755

[8] Memluk, Murat Z 2013 Designing Urban Squares, Advances in Landscape Architecture Murat Ozyavuz, IntechOpen, DOI: 10.5772/55826. Available from: https://www.intechopen.com/books/advances-in-landscapearchitecture/designing -urban-squares

[9] Sudharmono et al 2010 Toponim Surakarta Keragaman Budaya Dalam Penamaan Ruang Kota (Jakarta: Direktorat Georgrafi Sejarah, Direktorat Jenderal Sejarah dan Purbakala, Kementrian Kebudayaan dan Pariwisata)

[10] Lynch, K 1969 The Image of the City (Cambridge, Massachusetts: MIT Press)

[11] Kamus Besar Bahasa Indonesia (KBBI) Daring https://kbbi.kemdikbud.go.id/.

[12] Widjaja, HAW 2003 Otonomi Desa (Jakarta: PT Raja Grafindo Persada)

[13] Undang-Undang 32 Tahun 2004.

[14] Moughtin, Cliff 1999 Urban Design : Ornament and Decoration, Second Edition (Oxford: Architectural Press)

[15] Cuthbert, A R 2006 The Form of Cities: Political Economy and Urban Design (United Kingdon: Blackwell Publishing) 